\title{
Adenovirus replication is coupled with the dynamic properties of the PML nuclear structure
}

\author{
Vassilis Doucas, ${ }^{1,5}$ Alexander M. Ishov, ${ }^{2}$ Anthony Romo, ${ }^{1}$ Henry Juguilon, ${ }^{1,3}$ \\ Matthew D. Weitzman, ${ }^{4}$ Ronald M. Evans, ${ }^{1,3}$ and Gerd G. Maul ${ }^{2}$ \\ ${ }^{1}$ The Salk Institute for Biological Studies, La Jolla, California 92037; ${ }^{2}$ Wistar Institute of Anatomy and Biology, Philadelphia, \\ Pennsylvania 19104; ${ }^{3}$ Howard Hughes Medical Institute, ${ }^{4}$ Institute for Human Gene Therapy, University of Pennsylvania, \\ Philadelphia, Pennsylvania 19104 USA
}

\begin{abstract}
Wild-type PML and at least four other novel proteins are localized within discrete nuclear structures known as PODs. We demonstrate here that during adenovirus infection, immediate early viral proteins from the E1 and E4 transcription units associate with the POD, which in turn undergoes a dramatic morphological change. During this process, the auto-antigen Sp-100 and NDP55 but not PML, relocate from the POD to the viral inclusion bodies, the sites of adenovirus DNA replication and late RNA transcription. The E4-ORF3 11-kD protein alone will induce this reorganization and reciprocally, viruses carrying mutations in the E4-domain fail to do so. These same viral mutants are defective in viral replication as well as the accumulation of late viral mRNAs and host cell transcription shutoff. We show that interferon (INF) treatment enhances the expression of PML, reduces or blocks PODs reorganization, and inhibits BrdU incorporation into viral inclusion bodies. In addition, cell lines engineered to overexpress PML prevent PODs from viral-induced reorganization and block or severely delay adenovirus replication. These results suggest that viral replication relies on components of the POD and that the structure is a target of early viral proteins.
\end{abstract}

[Key Words: PML; Sp-100; POD; adenovirus replication; nuclear organization]

Received October 16, 1995; revised version accepted November 28, 1995.

In previous studies, we have identified a novel nuclear structure, referred to as ND10, Kr bodies, and the promyelocytic leukemia (PML) oncogenic domain or POD, whose integrity is disrupted in transformed cells from patients with acute promyelocytic leukemia (APL) (Ascoli and Maul 1991; Dyck et al. 1994; Koken et al. 1994; Weis et al. 1994). These patients harbor a $t(15 ; 17)$ translocation (Mitelman 1988) that fuses the PML nuclear protein to the retinoic acid receptor (RAR) and is the apparent etiologic agent of the transformation (de Thé et al. 1991; Kakizuka et al. 1991; Pandolfi et al. 1991; Chang et al. 1992; Goddard et al. 1992; Kastner et al. 1992). The leukemic fusion protein contains all but the amino terminus of the $\operatorname{RAR} \alpha$ and includes both the DNA-binding and ligand-binding domains. The RAR $\alpha$ gene is a key component for transformation as it is also disrupted in the $t(15 ; 17)$ leukemia (de Thé et al. 1991; Kakizuka et al. 1991). The PML-RAR fusion protein contains most of the amino-terminal portion of PML that includes the homology regions most likely to encode functional domains such as the cysteine-rich motif also known as the ring finger (Freemont et al. 1991). The ring finger family includes $>40$ proteins involved in a diverse array of functions including transcription control, DNA

${ }^{5}$ Corresponding author. replication, DNA repair, RNA processing, as well as several known oncogenes (Freemont et al. 1991; Kakizuka et al. 1991). In addition, PML contains a long putative $\alpha$-helical region including a leucine zipper that is required for PML homodimer formation as well as downstream PML functions (Kakizuka et al. 1991; Doucas et al. 1993; Perez et al. 1993). PML has been shown to modulate the activity of a set of downstream target genes, although it is not clear whether this is a direct or indirect effect (Doucas et al. 1993 and unpubl.; A. Kakizuka and R.M. Evans, unpubl.). Immunofluorescence studies have demonstrated that the POD is a macromolecular multiprotein complex that is present in all cultured cell lines examined and would appear to be widely expressed in the body (Dyck et al. 1994; Koken et al. 1994; Weis et al. 1994; J.A. Dyck and R.M. Evans, unpubl.). PODs can vary in number from 5 to 30 depending on cell type and although $\sim 0.5 \mu \mathrm{m}$ diameter, they can also vary substantially in size after interferon treatment or heat shock (Guldner et al. 1992; Maul et al. 1995). The PML-RAR oncoprotein is capable of forming a heterodimer through its helical region with wild-type PML precluding the formation of the POD resulting in a disperse or microparticulate state. This disruption by the oncoprotein is associated with cellular transformation and can be reversed by treatment of cells with RA /Grignani 
et al. 1993). In treated cells, intact PODs reform, followed by cellular differentiation (Dyck et al. 1994). Similarly, patients with APL can be induced into clinical remission after high-dose RA therapy (Huang et al. 1988; Castaigne et al. 1990). This work implies a potential role for PML and its associated proteins in normal cell cycle control such that disruption of the POD leads to a deregulation that is ultimately associated with cell transformation.

The above observations led us to consider a potential role for the POD in DNA replication and transcription and suggest that adenovirus might be exploited as tool to investigate this proposal. Adenovirus replication and transcription depends on host cellular components and can be divided into two phases relative to initiation of viral replication (Levine 1984; Halbert et al. 1985; Berk 1986; Schneider and Shenk 1987; Kenny et al. 1988). The early phase is initiated by expression of the early region 1A (E1A) and E4 transcription units followed by activation of E3, E1B, and finally E2 (Nevins 1987 and references therein). A variety of studies have demonstrated that several early proteins interact with specific cellular factors that both modulate viral and host gene expression. Thus, the E1A product is able to associate with retinoblastoma $\{\mathrm{RB}$ ), p107, p130, p300 (Dyson et al. 1989; Shirodkar et al. 1992), whereas the E1B 55-kD product is able to associate with p53 as well as other host factors (Sarnow et al. 1982a; Bargonetti et al. 1992; Yew et al. 1994). In addition, E1A/E1B are known to contribute to the activation of viral transcription units that in turn, control sequential stages of the viral replication cycle (for review, see Akusjarvi 1993). Importantly, as will be described in more detail below, viral infection leads to a dramatic morphologic change of the POD that is initiated by a combination of early gene products. Of particular interest, is the E4 transcription unit that produces a family of at least seven overlapping mRNAs (Berk and Sharp 1978; Freyer et al. 1984; Tiggs and Raskas 1984; Virtanen et al. 1984). The transcripts encoded by E4 give rise to several different translational open reading frames (ORFs) (Herisse et al. 1981; Cutt et al. 1987). The E4ORF3 and E4-ORF6 products are important in viral DNA replication, viral late protein synthesis, shut-off of host protein synthesis, and the production of infectious virus (Halbert et al. 1985; Weinberg and Ketner 1986). Thus, deletion of the E4 domain or selective deletion of these ORF3/ORF6 leads to a severe delay in the onset of adenovirus 5 (Ad5) replication as well as defects in the shut-off of the accumulation of host protein mRNA (Huang and Hearing 1989). In addition, ORF3/ORF6 mutants produce viral DNA concatemeres that lead to a "dead-end pathway" of viral replication (Weiden and Ginsberg 1994).

Late transcription and replication of Ad5 takes place in distinct regions that are associated with the nuclear matrix termed viral inclusion bodies or viral domains (Mariman et al. 1982; Puvion-Dutilleul et al. 1992; JimenezGarcia and Spector 1993; Pombo et al. 1994). The viral proteins E1B $55 \mathrm{kD}$, E2A (single-stranded DNA-binding protein or DBP|, and E4-ORF6 are localized in and around these inclusion bodies /Ornelles and Shenk 1991). In addition, E4-ORF6 and E1B $55 \mathrm{kD}$ form a protein complex, whereas E4-ORF3 associates with the nuclear matrix (Sarnow et al. 1982b, 1984).

The nuclear matrix, first described by Berezney and Coffee (1976), is a site of attachment of the viral inclusion bodies (Younghusband and Maundrell 1982) and virus assembly occurs on or in close association with the matrix (Khittoo et al. 1986). The ultrastructure of the nuclear matrix is altered during the last phase of the viral growth cycle (Zhai et al. 1987) and the adenovirus terminal protein mediates both nuclear matrix association and efficient transcription of adenovirus DNA (Schaack et al. 1990|. Considering the observation that PODs are tightly associated with the nuclear matrix and that the adenovirus replication domain is also attached to the matrix, it seems reasonable to examine the potential relationship between these two entities. We now demonstrate that at least two early transcribed viral proteins, E4-ORF3 $11 \mathrm{kD}$ and E1B $55 \mathrm{kD}$, are targeted to the POD, which in turn undergoes a major reorganization into a novel structure referred to as a track. During this process, some host components are recruited from the POD to the viral replication domain. We show that PML overexpression supresses both E4-ORF3 activity and virus replication. Similarly, interferon (INF) treatment both enhances the expression of PML and blocks the action of E4-ORF3 on POD dissociation. These results show the POD may sequester cellular proteins that may play a critical role in the early to late switch of adenovirus replication.

\section{Results}

The POD is the target of adenovirus early proteins

To explore the effect of viral infection on the structural organization of the POD, immunohistochemical experiments were performed on Hep- 2 cells infected with wildtype Ad5. As shown previously, PML and Sp-100 gave rise to a punctate nuclear staining pattern characteristic of the POD. Immunohistochemistry colocalizes PML (Fig. 1a) with Sp-100 (Fig. 1b) and NDP55 (Dyck et al. 1994) as well as with other human autoantibodies (not shown). However, within 5-8 hr after infection, PML and $\mathrm{Sp}-100$ begin to reorganize to a filamentous or tracklike structure. The filamentous structures defined by the PML (Fig. 1c) and Sp-100 (Fig. 1d) antibodies are of slightly different length and intensity and suggest a partial dissociation of PML and Sp-100 in the tracks (see also Fig. 4a, below).

As infection progresses [9-12 hr postinfection (p.i.)], PML and Sp-100 begin to segregate (Fig. 1e-g; data not shown), with Sp-100 relocating to a novel structure (Fig. lg) reminiscent of viral DNA replication domains (viral bodies). To confirm this identification we examined the staining pattern of the single-stranded DBP, which is known to localize within the viral replication domain (Ornelles and Shenk 1991 and references therein). Dual immunofluorescence experiments clearly demonstrate colocalization of E2A $72 \mathrm{kD}$ and Sp-100 at these sites 
Figure 1. Nuclear distribution of PML/ Sp-100 and Ad5 antigen in uninfected and Ad5-infected Hep-2 cells. (a) Distribution of PML (mAb 5E10) in precisely circumscribed nuclear domains; $|b|$, same as $a$ except Sp-100 labeling with mAb 1150; $(c)$ track-like distribution of PML in an Ad5infected cell at $8 \mathrm{hr}$ p.i. (mAb 5E10) after reconstructing six optical sections spanning the entire nucleus; (d) same as $c$ except Sp-100 labeling with mAb 1150; (e) single optical section of Ad5-infected cell labeled early after infection (6 hr) with mAb 1150 (Sp-100); $(f, g)$ same as $e$ but successively later (12 and $16 \mathrm{hr}$ p.i.) showing the appearance of the circular viral domains; $(h)$ same conditions as $g$ the cells are labeled only with mAb 138 (NDP55); (i) DBP in viral domains; $(j)$ same as $i$ except Sp-100 labeling with a rabbit polyclonal antibody showing that DBP and $\mathrm{Sp}-100$ are in the same domains; $(k)$ E4-ORF6 gene product localization with ORF6 $\mathrm{mAb}$ M45 in wild-type Ad5-infected cell to viral domains but also diffusely throughout the nucleus; (1) ElB 55-kD (Oncogene Sc.) protein localizes throughout the nucleus and viral domains.
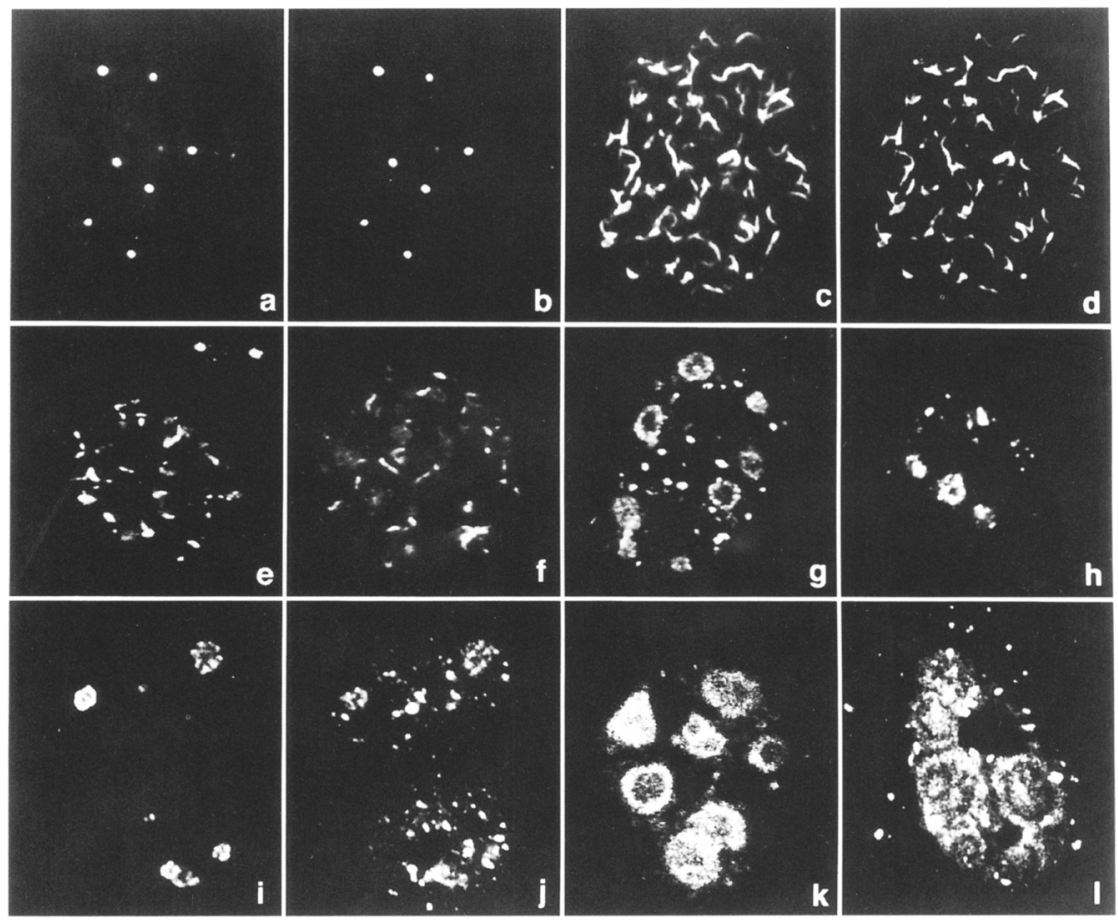

(Fig. $1 \mathrm{i}, \mathrm{j}$ ) with diminished staining of $\mathrm{Sp}-100$ in tracks. The identification of the viral replication domain was substantiated further by localization of the E4-ORF6 (Fig. $1 \mathrm{k}$ ) and E1B $55-\mathrm{kD}$ proteins (Fig. 11). ElB (5-8 hr p.i.) is found first in the cytoplasm and nuclear deposits and then expands in the replication domain, whereas the E4 ORF6 product has an initial diffuse nuclear distribution and later localizes in the viral domain (Ornelles and Shenk 1991). At $12 \mathrm{hr}$ p.i. Sp-100 is in a dynamic flux redistributing from the POD to the viral domains as well as showing a less defined granular pattern within and around these viral replication sites (Fig. 1, cf. $f$ and $g$ ). Similar results were seen with mAb 138 for NDP55 (Fig. $1 \mathrm{~h}$; data not shown).

The kinetic analysis of the relocation shows that tracks containing PML and Sp-100 appear 5-6 hr p.i. followed by $\mathrm{Sp}-100$ in viral domains $\sim 4 \mathrm{hr}$ later (Fig. 2). The presence of $\mathrm{Sp}-100$ but not the PML in tracks diminishes over time as the intensity of fluorescence increases in the viral domains (see Fig. 1g). From the sequential appearance of the two structures during infection, we conclude that the formation of the tracks is an early event, whereas the redeployment of Sp-100 and NDP55 is a later event correlated with the initiation of viral DNA replication and late transcription.

\section{Viral proteins trigger PML reorganization}

To determine which viral proteins may be responsible for the redistribution of PML and Sp-100, we have made use of extensively characterized Ad5 mutants. As shown in Tables 1 and 2 and Figure $3 \mathrm{~b}$, deletion of the entire E4 transcription unit $\left(\mathrm{d} 1366^{*}\right)$ prevents PML redistribution. In contrast, mutations in the E3 domain (dl309) result in a redistribution of PML that is similar to wild-type Ad5 (Figs. 1c and 3a). A double deletion of E1A and E1B (Ad CB) still allows PML reorganization, although in a greatly delayed fashion occasionally producing unusually long tracks (24-48 hr p.i.) (Table 1; Fig. 3f). This mutant virus also delays the onset of viral gene transcription (Nevins 1987).

These results suggest that one or more viral proteins produced by the $\mathrm{E} 4$ region are critical for the redistribution of PML. E4 codes for seven ORFs that arise by alternative RNA processing. Analysis of deletion mutants reveals that a double mutation of ORF3 and ORF6 prevents PML structural reorganization (Table 2; Fig. $3 \mathrm{~d}$ ). Mutation of only ORF6 (dl355) delays the appearance of PML tracks (8-12 hr p.i.) (Table 2), whereas an ORF3 deletion (inORF3) both delays and severely decreases the number of infected cells scored positive for track formation (Fig. 3c; Table 2). The above results suggest a partially redundant and potentially cooperative effect between these two proteins. Finally, an E4 mutant that only expresses ORF3 (dl366* + ORF3), induces efficient POD reorganization similar to wild-type Ad5 (Fig. 3e). These results suggest that the E4-ORF3 $11-\mathrm{kD}$ viral protein is sufficient to promote PML reorganization but that other E4 proteins can influence the process. The above experiments were performed at a relatively low [4-20 plaque-forming units (PFU)/cell] multiplicity of inflection (m.o.i.). Nonetheless, at a higher m.o.i. (CV1 and $100 \mathrm{PFU} /$ cell), Ad5 di $366^{*}$, or the $\mathrm{E} 4$ inORF3/inORF6 mutants display a limited ability to reorganize PML and 


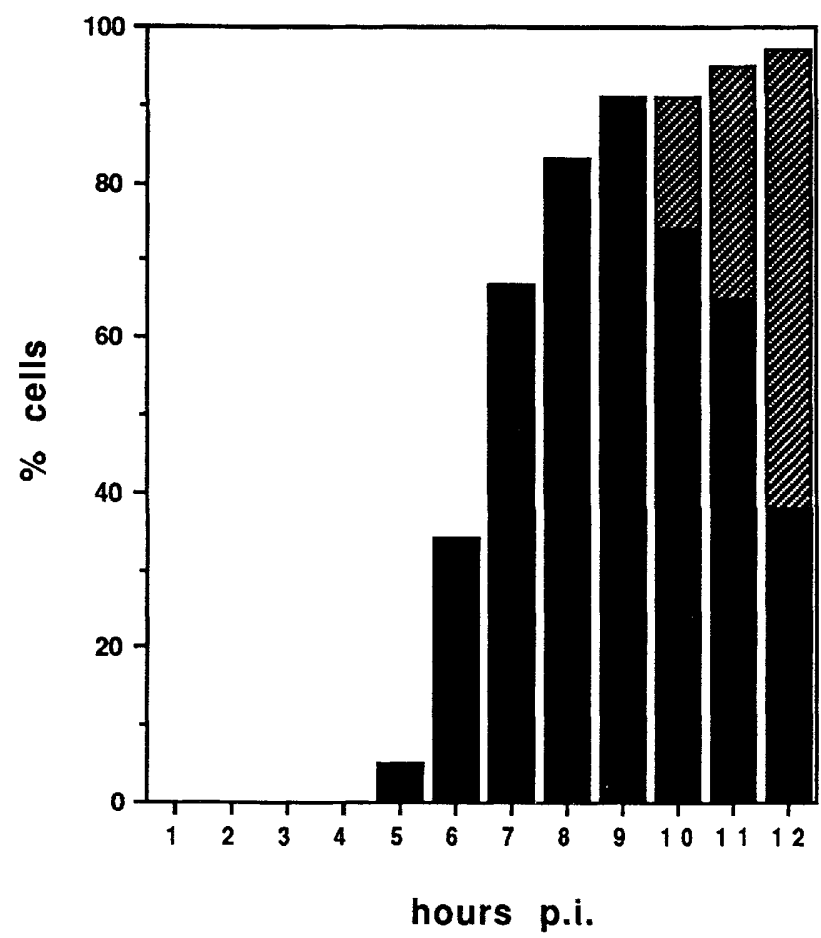

Figure 2. Time sequence of $\mathrm{Sp}-100$ appearance in tracks and viral domains. Hep-2 cells infected with wild-type Ad5 at a multiplicity sufficient to infect $95 \%$ of Hep- 2 cells productively were used and the cells fixed at hourly intervals. They were scored as having tracks or viral domains recognized by $\mathrm{mAb}$ 1150 (Sp-100). Cells with only tracks are represented by solid bars, whereas any cell that showed a viral domain regardless of the presence of tracks are represented by hatched bars. There is a 3- to 4-hr delay in the appearance of Sp-100 in viral domain under the conditions used. Higher infectious virus input can make this curve steeper. At least 100 cells were scored for each time point in each of three (or more) independent experiments.

Sp-100 into track-like structures (data not shown). Also, high m.o.i. partially overcomes the severe replication defects of these mutants (Huang and Hearing 1989). These results imply that ORF3/ORF6 facilitate or promote a rate-limiting step in the transition between early and late viral functions.

Because the distribution of Sp-100 changes with time (see Fig. 1e-g), we examined other Ad5 mutants to see whether they can prevent or modulate this process. The results, summarized in Table 1, chart the appearance of Sp-100 into tracks and viral domains and identify three general classes of virus-host interactions: one that allows formation of both tracks and localization of Sp-100 to viral domains (i.e., wild-type and E3 deletion), another with no track formation but with delayed appearance of Sp-100 to viral domains (E4, E4-ORF3/ORF6 deletion), and the third with only track formation but no relocation of Sp-100 (E2A; E1A/E1B blockage of DNA replication and no viral domain formation).

Ad5 dl366* (Fig. 3b) and Ad5 dl1004 (Fig. 4c,d) are unusual in that tracks are not formed at any time after infection at a m.o.i. of $\leqslant 20$ PFU per cell. The results
Table 1. Hep-2 cells infected with Ad5 viral mutants

\begin{tabular}{|c|c|c|c|}
\hline $\begin{array}{l}\text { Virus } \\
\text { designation }\end{array}$ & $\begin{array}{l}\text { Affected viral } \\
\text { protein }\end{array}$ & $\begin{array}{l}\text { PML-1 } \\
\text { (Tr.; VD) }\end{array}$ & $\begin{array}{l}\text { Sp-100 } \\
\text { (Tr.; VD) }\end{array}$ \\
\hline Ad5 & wild type & $+;-$ & $+;+$ \\
\hline $\mathrm{Ad} C \mathrm{CB}$ & $\mathrm{E} 1 \mathrm{~A}, \mathrm{E} 1 \mathrm{~B}$ & $+;-$ & $+;-$ \\
\hline dl110 & E1B $55 \mathrm{Kd}$ & $+;-$ & $+;+$ \\
\hline dl7001 & E3 & $+;-$ & $+;+$ \\
\hline $\mathrm{d} 1309$ & E3 & $+;-$ & $+;+$ \\
\hline dl1004 & $\mathrm{E}^{-}+\mathrm{ORFl}$ & $-;-$ & $-i+$ \\
\hline dl366* & $\mathrm{E} 4^{-}$ & $-;-$ & $-;+$ \\
\hline dl802 & E2A & $+;-$ & $+;-$ \\
\hline
\end{tabular}

Hep-2 cells infected with the indicated Ad5 viral mutants at 4-20 PFU were fixed at $\sim 6,12$, and $24 \mathrm{hr}$ p.i. and tested in immunofluorescence studies with PML and Sp-100 antibodies for track formation ( $\mathrm{Tr}$ ) and localization to viral inclusion domains (VD). They are scored as positive $(+)$ or negative $(-)$, and consistent results were obtained at each of the three times after infection assayed. Mutation of E1A and E1B delayed (16-48 hr p.i.) the appearance of tracks and blocked the formation of viral domains. The $\mathrm{E} 4$ mutations blocked the formation of tracks and delayed the presence of $\mathrm{Sp}-100$ in the viral domains.

obtained with Ad5 CB (E1A $\left.{ }^{-} / \mathrm{E}^{-} \mathrm{B}^{-}\right)$, dl1004, and dl366* suggest that viral DNA replication may be required for the redistribution of Sp-100 (and NDP55) to viral domains and that track formation may be required for early replication at low m.o.i. To analyze further this proposal we tested Ad5 dl802 in which viral DNA replication is blocked by partial deletion of the DBP (E2A $72 \mathrm{kD}$ ) (Rice and Klessing 1985). This mutant produced large and long-lasting tracks for both PML and Sp-100 (Fig. 4e). E1B $55 \mathrm{kD}$ was present in these tracks (Fig. 4f), but no viral domains were formed. Thus, formation of tracks is independent of viral DNA replication and Sp-100 relocates from tracks only when replication domains form.

Table 2. CV-1 cells infected with E4 domain Ad5 mutants

\begin{tabular}{llc}
\hline $\begin{array}{l}\text { Virus } \\
\text { designation }\end{array}$ & $\begin{array}{l}\text { Affected viral } \\
\text { protein }\end{array}$ & $\begin{array}{l}\text { PML reorganization } \\
\text { track formation }\end{array}$ \\
\hline in351 & ORF1 & + \\
in352 & ORF2 & + \\
dl355 & ORF6 &,+ delayed \\
dl356 & ORF6/7 & + \\
dl358 & ORF4 & + \\
dl359 & ORF4 & + \\
inORF3 & ORF3 & $-/+$, delayed \\
inORF3/inORF6 & ORF3/ORF6 & - \\
dl366 + ORF3 & E4 ${ }^{-}+$ORF3 & + \\
dl366* & E4 & - \\
\hline
\end{tabular}

CV-1 cells were infected with 4-20 PFU and fixed at $\sim 6,12$, and $18 \mathrm{hr}$ p.i. and tested in immunofluorescence studies with PML antibody 1124 for track formation. They are scored as positive $(+)$ or negative $(-1$. Consistent results were obtained at each time tested. Track formation appears at $\sim 6 \mathrm{hr}$ p.i. in the majority of the mutants as in the wild-type Ad5. As indicated, an ORF6 mutation delayed the track formation (8-12 hr p.i.), whereas an ORF3 mutation not only delayed but severely reduced the appearance of tracks. 
Figure 3. Blockage of PML relocalization in an Ad5 E4- background. CV1 cells were infected with Ad5 mutant virus with $\sim 10$ PFU per cell. Cells were fixed $12 \mathrm{hr}$ later $(a-e)$ or $48 \mathrm{hr}$ p.i. $(f)$ and labeled for PML with the peptide antibody 1124 as described in Materials and methods. Cells were infected with the following viral mutants: $(a)$ dl309; (b) dl $366^{*} ;(c)$ E4 inORF3; (d) E4 inORF3/inORF6; (e) dl366* + ORF3; and $(f)$ Ad5 CB. The reorganized PML pattern shown in $c$ is observed only after a substantial delay (i.e., $12 \mathrm{hr}$ p.i.) or after a high m.o.i. (>100 PFU) with E4 inORF3 mutant virus. All of the cells were double labeled with a monoclonal antibody detecting the E1B $55 \mathrm{kD}$ or E4-ORF6 gene product to control infection (data not shown).



The E1B $55-k D$ protein transiently colocalizes with PML and Sp-100

Although the E1B $55-\mathrm{kD}$ protein is not required for formation of tracks or viral domains (Table l) the replication-defective mutant dl 802 (Fig. 4f) revealed striking colocalization of E1B in tracks with PML and Sp-100. This suggests that ElB might be localized transiently to tracks but relocates during viral domain formation. To explore this proposal we examined the temporal pattern of E1B $55 \mathrm{kD}$ and PML distribution after infection (Fig. 5; data not shown). E1B is seen in a reorganized PML-containing structure (Fig. $5 \mathrm{c}$ ) in an infection with dl309 or infection with viral mutant E4 inORF3 (Fig. 5d) as well as in intact PML body (Fig. 5a,b), after infection with dl366*. We conclude that E1B $55 \mathrm{kD}$ localizes transiently with PML. This result suggests that E1B $55 \mathrm{kD}$ could contribute to the sequential redistribution of $\mathrm{POD}$ proteins. The E4-ORF6 protein forms a complex with
E1B $55 \mathrm{kD}$ (Sarnow et al. 1984), and thus, both appear in the viral domains (see Fig. $1 \mathrm{k}$ ) together with $\mathrm{Sp}-100$ and NDP55 proteins .

\section{The E4-ORF3 promotes track formation}

To determine whether ORF3 is sufficient to promote POD reorganization we cloned its coding sequence by PCR amplification (see Materials and methods) and placed this into an expression vector under the control of the cytomegalovirus (CMV) promoter. Transient expressed epitope-tagged ORF3 in CV1 cells colocalizes initially with PML in an intact POD (Fig. 6a). This image is rare as E4-ORF3 quickly induces a dramatic change in PML distribution (Fig. 6b), in a fashion similar to wildtype Ad5 (see Fig. lc). The same reorganization is obtained with an expression vector lacking the epitope-tag (not shown). In a double-immunofluorescence experi-
Figure 4. Different phenotypes obtained with various Ad5 deletion mutants by double labeling with antibodies to virus and host proteins. (a) PML (mAb 5E10; Texas Red) and Sp-100 (rabbit antiSp-100; FITC green) double labeling of tracks in wildtype Ad5-infected cells $12 \mathrm{hr}$ p.i. showing that $\mathrm{Sp}-100$ is segregated partially to viral domains; (b) E1B $55 \mathrm{kD}$ [mAb /Oncogene Science; Texas Red)] and Sp-100 [rabbit anti Sp-100; FITC) in wild-type Ad5-infected cells $12 \mathrm{hr}$ p.i. demonstrating that E1B $55 \mathrm{kD}$ locates to tracks. Ad5 deletion mutants $1004\left(\mathrm{E} 4-\mathrm{ORFl}^{+}\right)(c, d)$, and $\mathrm{dl} 802$ (DBP deletion) $\{e, f\}$ were fixed and stained, respectively, like the wild-type series $(a, b)$. All images are single optical sections. The yellow color in these double exposed images indicates the sites where PML and Sp100 or E1B and Sp-100 colocalize.
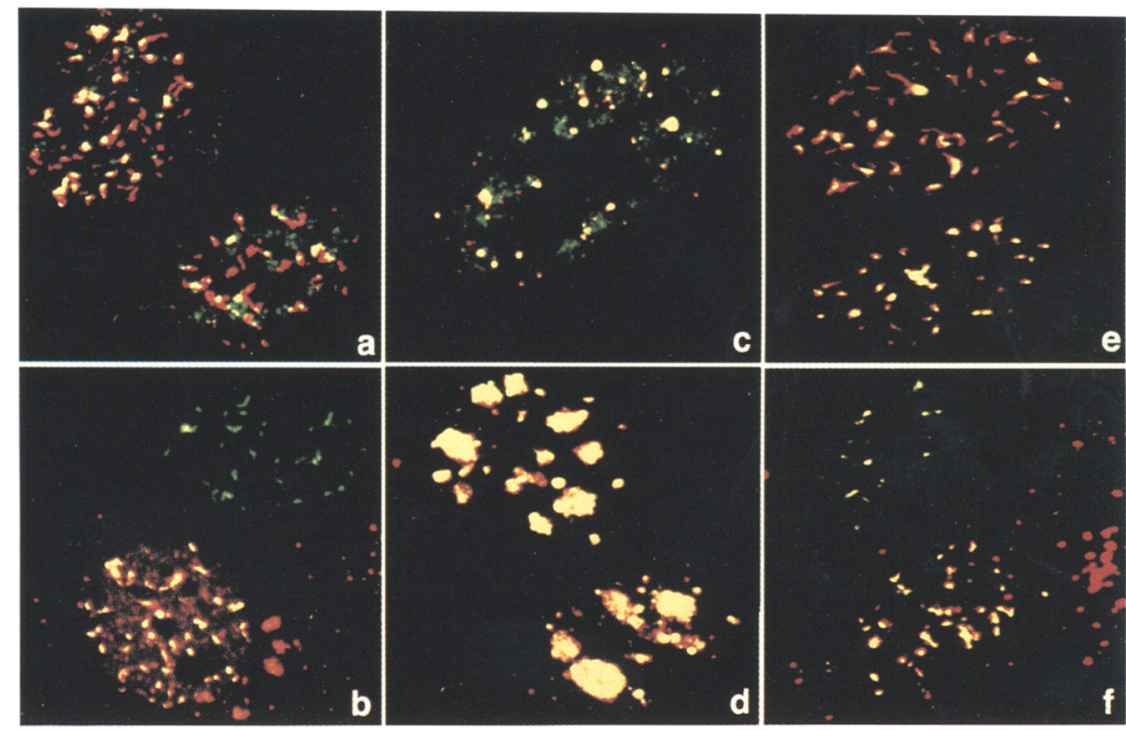


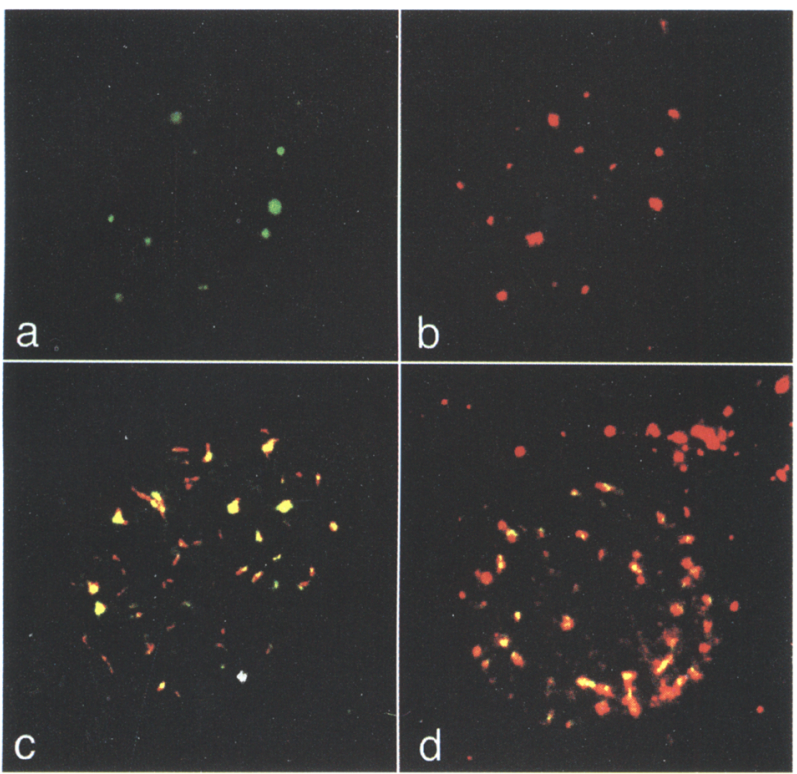

Figure 5. ElB $55 \mathrm{kD}$ and PML colocalization. CVl cells were infected, respectively, with the following viral mutant: $|a, b|$ d1366*; (c) dl309, and $(d)$ dlE4 inORF3, with $\sim 10$ PFU per cell. Cells were fixed at $12 \mathrm{hr}$ p.i. and labeled: $(a)$ for PML (peptide antibody 1124, FITC); (b) for E1B 55-Kd viral protein (mAb 2A6; Texas Red); (c) labeled for E1B $55 \mathrm{kD}$ (mAb 2A6; FITC) and for PML (peptide antibody 1124; Texas Red); (d) labeled for E1B 55 $\mathrm{kD}$ (mAb 2A6; Texas Red) and for PML (peptide antibody 1124; FITCl, as described in Materials and methods. $a$ and $b$ are singleexposed, $c$ and $d$ are double-exposed. The yellow color in the double-exposed images indicates the sites where PML and E1B $55 \mathrm{kD}$ colocalize.

ment we observed that the HA.ORF3 appears in tracks and is colocalized with endogenous PML (Fig. 6c) and Sp-100 (data not shown). In contrast to ORF3, transient transfection of CMV-ORF6 expression vector (data not shown) does not promote reorganization suggesting that it is neither necessary nor by itself sufficient to alter POD morphology.

To explain the dynamics of POD reorganization in the presence of ORF3 we ask whether coexpression of either PML or Sp-100 can reverse this process. Remarkably, overexpression of PML blocked E4-ORF3-induced track formation. Simultaneously, the PODs dramatically enlarged (Figs. 1a and 6d) accumulating protein in expanded PML domains appearing as large yellow/orange dots /Fig. $6 \mathrm{~d})$. In contrast, overexpression of $\mathrm{Sp}-100$ does not block ORF3-induced reorganization but, rather, promotes formation of these proteins in long tracks similar to the ones observed with Ad5-infected cells (see Fig. 1d; data not shown). Expression of PML together with Sp-100 and ORF3 in a cotransfection assay suppressed track formation again favoring the appearance of the enlarged PODs. In view of the potential relevance of the $\alpha$-helical region in the PML for the in vivo direct or indirect interaction with ORF3, we investigated the effect of the deletion of 60 amino acids destroying the main dimerization do- main of PML (see Materials and methods). In transfection experiments we find that PML $\Delta \mathrm{lz}$ no longer exhibits an intact POD-staining pattern but in contrast exhibits a diffuse homogenous nuclear and cytoplasmic distribution (Fig. 6e). In addition, ORF3 does not associate with PML $\Delta l z$ but, as expected, still targets the endogenous POD structure inducing its reorganization (Fig. 6d-f).

\section{POD reorganization is linked to efficient viral replication}

The above results suggests that in a wild-type infection the accumulation of E4-ORF3 in the POD itself acts to antagonize a functional property of PML (or a PML-associated factor) and thus triggering track formation. As shown in Figure 6d, transient expression of PML blocks ORF3-induced track formation. Taking into consideration that E4-ORF3 stimulates the efficiency of viral propagation $>2000$-fold (Huang and Hearing 1989), two additional approaches were devised establishing a link between POD reorganization and viral replication. The first involves transient induction of POD-associated proteins by INF- $\beta$ treatment. The second involves continuous overexpression of PML in stably transformed cell lines. In the first case, Hep-2 cells were pretreated with INF- $\beta$ before infection with dl366* + ORF3. This Ad5 mutant is able to induce POD reorganization and replicates normally. As shown previously, INF treatment dramatically increases expression of POD-associated proteins, such as Sp-100 and PML (Guldner et al. 1992; data not shown) and represses $\mathrm{dl} 366^{*}+\mathrm{ORF} 3$ replication (at 9 and $18 \mathrm{hr}$ p.i.; Fig. 7a). Double immunofluorescence combined with bromodeoxyuridine (BrdU) pulse labeling reveals that track formation and BrdU incorporation in viral inclusion bodies is reduced severely in these cells. Thus, these results suggest that viral DNA synthesis and POD reorganization are suppressed by the increased synthesis of PML and associated proteins. Because INF- $\beta$ treatment could have multiple effects we have engineered cell lines to overexpress PML stably (see Materials and methods). One common characteristic of these cells is the presence of enlarged PODs as evidenced by immunohistochemistry with both PML antibody and Sp100 antibody. In a series of independently isolated Hep-2 cells lines (termed LPIS1-LPIS4; elpis is the Greek word for hope) replication of $\mathrm{d} 1366^{\star}+\mathrm{ORF} 3$ is inhibited dramatically. Again, replication is determined by measuring the amount of viral DNA, by Southern blot, at the indicated times after infection. In addition, BrdU incorporation in viral domain is similarly reduced /data not shown). These results, along with the data in Fig. 6b-d show that increased expression of PML by either transient transfection, stable vector expression, or INF treatment, inhibit E4-ORF3 action to dissociate the POD. We conclude that this event delays or blocks Sp-100/ NDP55 recruitment to the viral replication domains resulting in the inhibition of viral DNA replication. Because deletion of ORF3 in adenovirus mutants blocks or delays adenovirus replication (Table 2; Huang and Hear- 
Figure 6. Distribution of E4-ORF3, PML and $\mathrm{Sp}-100$ in transfected cells. $(a-c) \mathrm{CV} 1$ cells transfected with the CMV-HA.ORF3 expression vector. Cells were fixed and double labeled for PML with the polyclonal antibody 1124 using a second monocolonal antibody FITC conjugated and for E4-ORF3 with the mAb 12CA5 using a second $\mathrm{mAb}$ Texas-red conjugated. (a) Double labeling of PML and ORF3 localization in intact PODs; $(b)$ PML localization in tracks; $(c)$ the same image as $b$ but a double exposure showing the colocalization of PML and ORF3 in tracks. ( $d-$ f) Fixed Hep- 2 cells transfected with the following expression vectors; (d) CMXPML and CMX-HA.ORF3; $(e, f)$ pSVPMLAlz and CMX-HA.ORF3. (d) A double exposure showing that PML (rabbit antibody 1124; FITC) and ORF3 (mAb 12CA5; Texas Red) colocalized in enlarged PODs. The images in $e$ (detection of PML) and $f$ (detection of E4-ORF3) are the same. The yellow color in the double exposed images indicates the sites where PML and E4ORF3 colocalize.

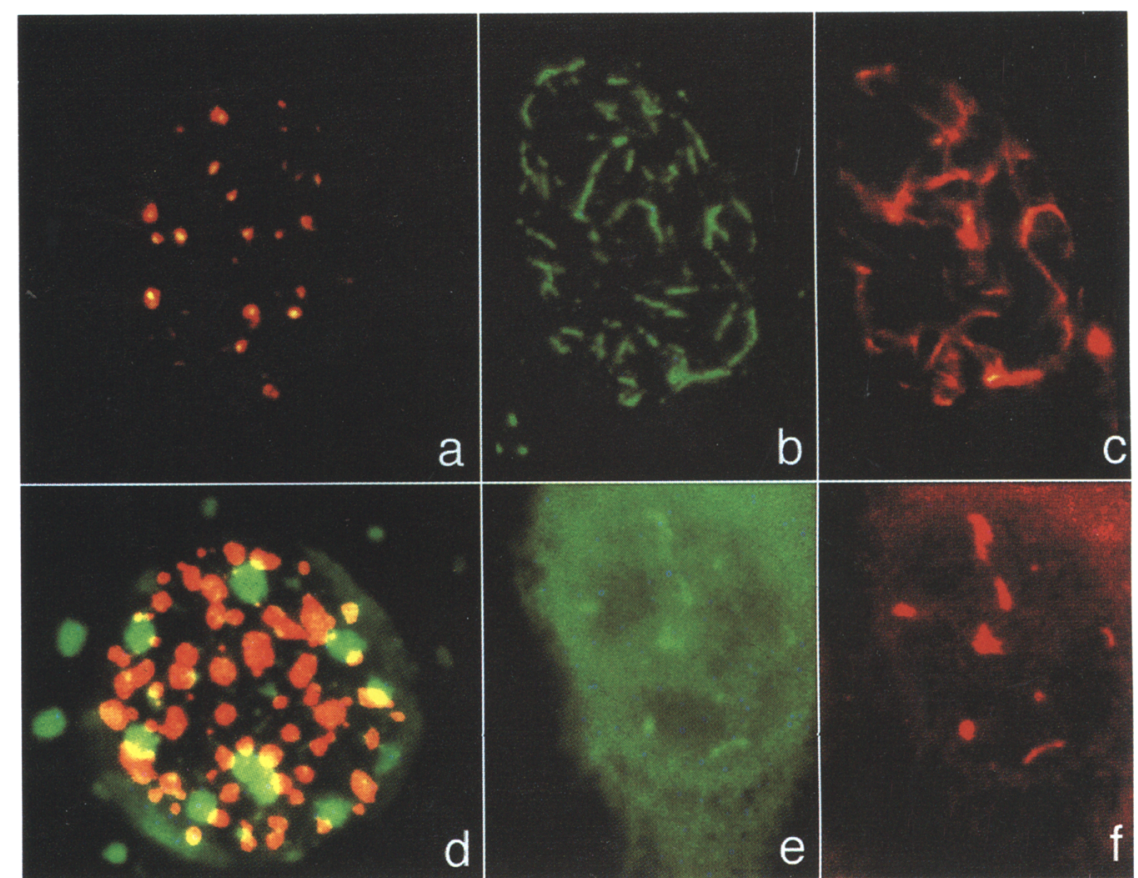

ing 1989), we conclude that the POD is the site of action of ORF3.

\section{Discussion}

In previous studies we have explored the oncogenic properties of the PML-RAR fusion protein using a combination of immunohistochemical and functional techniques. Wild-type PML localized to a novel nuclear domain (Ascoli and Maul 1991), which we refer to as a POD
(Dyck et al. 1994). Expression of the fusion protein in APL cells precludes formation of this structure, presumably as a consequence of the interaction with wild-type PML. In this study we have used Ad5 as a tool to study the potential contribution of the POD to the progression of viral infection. In a fashion similar to APL, virus-infected cells disrupt POD integrity. This is first observed by dramatic morphologic changes resulting in the loss of spherical bodies and the appearance of fibrous-like tracks. Using antibodies to spatially localize PML and a

Figure 7. PML suppresses viral DNA replication. $|a|$ Hep-2 cells were incubated in the presence (lanes 2,4 ) or in the absence (lanes 1,3 ) of INF- $\beta$ for $18 \mathrm{hr}$ before infection with Ad5 dl366 * ORF3 viral mutant at 4-8 PFU per cell. Southern blots of DNA from infected cells isolated at 9 and $18 \mathrm{hr}$ p.i. (lanes 1,2 and 3,4, respectively) were hybridized with E1A probe. All lanes contain E1A HindIII-digested DNA that migrates at $2.8 \mathrm{~kb}$. (b) A Southern blot, as in $a$, of Hep- 2 and Hep- 2 LPIS cells (LPISpool, LPIS1, LPIS2, LPIS3, LPIS4) infected with dl366* + ORF3. Cells were infected at confluency with 4 PFU for the indicated time points. The amount of ElA probe that hybridized on the nitrocellulose filter was counted in a PhosphorImager and the values obtained are represented in the histogram in arbitrary units, (Open bar) $16 \mathrm{hr}$ p.i.; (solid bar) $32 \mathrm{hr}$ p.i. b
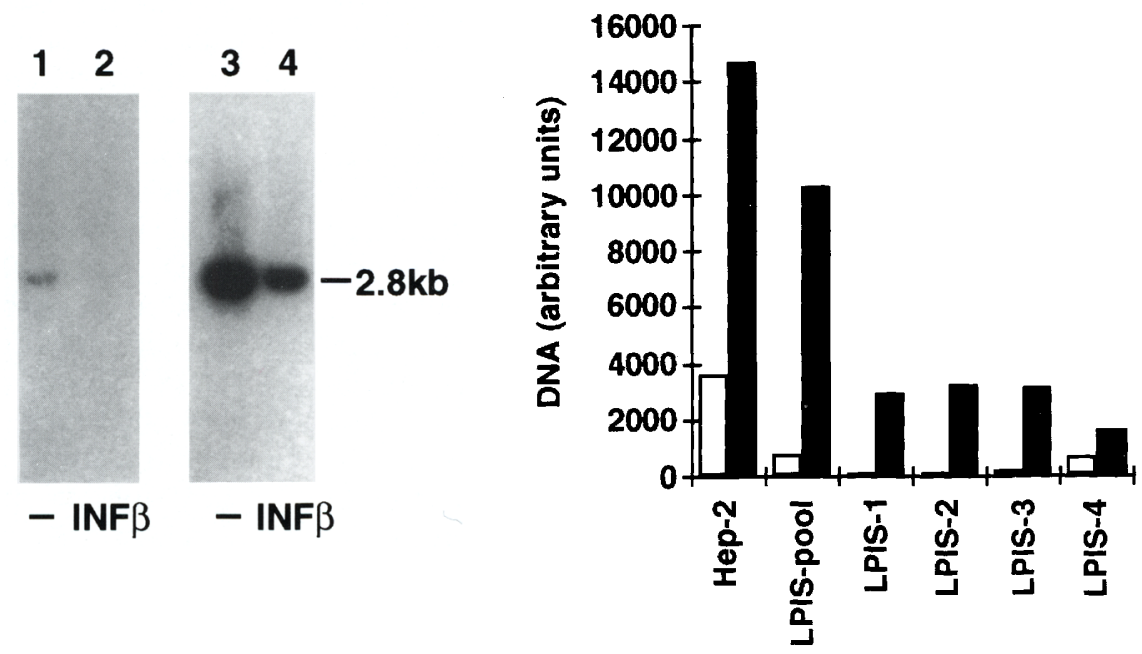

Cell Lines 
associated proteins, we were able to link the morphologic changes with specific events of the virus life cycle. The combined temporal/spatial approach reveals that some POD proteins, such as Sp-100 and NDP55, are redeployed in this process to the site of viral DNA transcription and replication. In contrast, PML does not enter the viral domain but rather, remains in complex with viral and residual POD proteins. We demonstrate that a visible morphologic change is caused by a product of $\mathrm{E} 4$ transcription unit that produces at least six different proteins. We demonstrate that a double mutation in the E4-ORF3/ORF6 gene product completely blocks POD reorganization and that transient transfection of CMXHA.ORF3 expression vector promotes track formation in noninfected cells. These results suggest that Ad5 is coordinating a series of sequential events in an effort to recruit host factors to active sites of viral replication/ transcription. Similarly, other host factors such as NF1, which is required for DNA replication, are also transported to the viral domains after infection (Mul et al. 1990; Bosher et al. 1992).

Intrinsic to the idea of protein recruitment is the notion that these proteins while in the POD, are functionally inaccessible and thus, unable to participate in the viral program. Thus, a critical goal of the virus would be to promote release of these otherwise limiting molecules from an inactive nuclear compartment to active sites of viral replication. This model is similar to that proposed recently by Jimenez-Garcia and Spector (1993) in which transcription and splicing factors are redistributed from interchromatin granule clusters to sites of viral RNA transcription.

\section{Virus-host interactions}

The analysis of Ad5 mutants along with immunohistochemical characterization of their wild-type counterparts highlights at least two steps in POD reorganization. First, immediately after infection in CVl cells, the E1B 55-kD protein becomes colocalized with wild-type POD. Previous studies have shown that E1B ultimately becomes localized to replicative foci and forms a complex with E4-ORF6 that functions to promote accumulation of late viral mRNA while simultaneously restricting the accumulation of host cellular RNA by probably interacting with a cellular factor (Ornelles and Shenk 1991). Second, E4-ORF3/ORF6 initiates the characteristic morphologic transformation that precedes protein relocalization. Because the E4-ORF3 product alone is able to promote reorganization, whereas ORF6 is not, we deduce that ORF3 is the critical trigger of the visible reorganization. This viral product is conserved immunologically between all the human adenovirus serotypes A-E (Sarnow et al. 1982b). Although overexpression of PML will block ORF3-induced reorganization, PML and ORF3 do not interact in an in vitro coimmunoprecipitation assay. Thus, the ORF3-interacting factor remains unidentified.

It is important to note that in an $\mathrm{E}^{-}$virus background both viral replication and late viral transcription is se- verely repressed but can be overcome partially by a high m.o.i. (Huang and Hearing 1989). In this case, Sp-100 and NDP55 become transported in a delayed fashion to the slowly expanding viral replication domains (data not shown|. This supports a proposal in which the E4 gene products function to accelerate the release of the host components and therefore promote efficient viral replication. It is not yet clear whether viral proteins (such as E1B) facilitate the movement of host factors to viral replication/transcription sites. Alternatively morphological change induced by E4-ORF3/ORF6 gene products may reflect the release of cellular factors, which then diffuse to the viral domains. In either case we presume that the ability of E4-ORF3/ORF6 to induce reorganization is linked to its action on viral proliferation (Halbert et al. 1985; Bridge and Ketner 1989; Huang and Hearing 1989). The E4-ORF3/ORF6 gene products promote track formation and augment viral DNA replication. In contrary to E4-ORF6, which is diffused in the nucleoplasm or in the viral replication domains, the ORF3 $11-\mathrm{kD}$ protein appears to be immunologically restricted to PODs and tracks. Interestingly, the absence of ORF3/ORF6 leads to formation of viral DNA concatemers (Weiden and Ginzberg 1994), which leads to proportionate reduction in virus titer. In turn, this suggests that DNA processing may be one potential function of cellular proteins relocating from the POD to the viral domain.

Previous results have indicated that the PML-RAR oncoprotein precludes formation of the intact PODs. In the case of APL, RA treatment leads to a reassociation of the POD and differentiation of the cells. Together with the adenovirus data, these results suggest a putative role for the POD and POD-associated proteins in the progression of normal cells through the cell cycle and in facilitation of the viral replication/transcription pathway. The results also suggest that the release of POD proteins triggered by the expression of the PML-RAR oncoprotein may promote cellular events analogous to the activation of the viral program. This model would suggest that the POD may represent a depot or nuclear compartment that sequesters regulatory proteins whose activities or soluble levels must be tightly regulated. Disnuption of this regulation by either PML-RAR or E1B/E4, may trigger precocious entry into $S$ phase or DNA replication, or both. In conclusion, it would appear that the use of adenovirus and adenovirus mutants provides an effective approach to study the dynamic nature of the PML nuclear body and its role in both viral infection and cell cycle control.

\section{Materials and methods}

\section{Cell and virus culture}

CV1 cells were maintained as monolayers in Dulbecco's modified Eagle minimal essential medium (DMEM) supplemented with $10 \%$ bovine calf serum (GIBCO Laboratories) and 100 $\mathrm{U} / \mathrm{ml}$ of penicillin-streptomycin. Cultures were maintained at $37^{\circ} \mathrm{C}$ in $8 \% \mathrm{CO}_{2}$. Hep-2 carcinoma cells were maintained in DMEM supplemented with $10 \%$ fetal calf serum in a humidified atmosphere containing $5 \% \mathrm{CO}_{2}$. For immunofluorescence, 
cells were grown on round coverslips (Corning Glass Inc.) in 6or 24-well plates.

Both wild-type Ad5 and a phenotypically wild-type virus (dl309), which served as parent to several mutants, (Jones and Shenk 1979), are used in this study. The following mutant viruses were used: d1338, which has a deletion in the carboxyl terminus of the ElB 55-kD protein (Pilder et al. 1986); dl366 with a deletion of E4-coding sequences positioning between 98.4 map units (m.u.) and $92.1 \mathrm{mu}$; dl355, which carries a 14-bp deletion that destroys the E4 34-kD protein (E4-ORF6); dl356 lacking 2 bp that destroys the E4-ORF6/ORF7 gene product; dl358 and dl359 with 20- and 30-bp deletions, respectively, that inactivate the E4-ORF4 gene product; in351 and in352 with insertion mutations that inactivate, respectively, E4-ORF1 and E4-ORF2 gene products (Halbert et al. 1985; Cutt et al. 1987); dl366* carries the dl366 E4 deletion in an E3 ${ }^{+}$background; E4 inORF3 (inORF3) contains an 8-bp insertion at 96.4 m.u. of the Ad5 genome that inactivates E4-ORF3 gene product; E4 inORF3/E4 inORF6 (inORF3/inORF6) contains an 8-bp insertion at $93.0 \mathrm{~m}$.u. that destroys E4-ORF6 gene and an 8-bp insertion at 96.4 m.u. of the Ad5 genome that inactivates the E4-ORF3 gene product; $\mathrm{dl} 366^{\star}+$ ORF3 was constructed by inserting restriction endonuclease fragments containing E4-ORF3 into dl366* mutant virus (Huang and Hearing 1989).

The sequences spanning 78.4-86 m.u. are deleted in the E3 mutant virus $\mathrm{H} 5 \mathrm{dl} 7001$. The E1B mutant $\mathrm{H} 5 \mathrm{dl} 110$ carries a lesion expected to disrupt only the $55 \cdot \mathrm{kD}(469 \mathrm{R})$ product of $\mathrm{ElB}$ (Babiss and Ginsberg 1984). The E4 mutant H5dl1004 is deleted for all E4-coding regions except ORF1 (Bridge and Ketner 1989). The E2A mutant virus $\mathrm{H} 5 \mathrm{~d} 1802$ contains a deletion in the gene for the 72-kD DBP (Rice and Klessing 1985) and was propagated on the complementing HeLa-derived cell line gmDBP6 (Brough et al. 1992). Ad CB is an E1-deleted recombinant Ad5 expressing the lacZ gene (Berkner 1992; Kozarsky et al. 1993).

All viruses with disruptions in the $\mathrm{E} 4$ region were propagated on the Vero-derived complementing cell line W162 (Weinberg and Ketner 1983). The wild-type Ad5, H5dl7001, H5dll10, dl338, dl309, and Ad CB were propagated in human 293 cells (Graham et al. 1977). For virion preparation cells were infected at an m.o.i. equal to 5 PFU per cell.

To analyze the effects of viral gene products on POD structure, cells growing on round coverslips at $50 \%-80 \%$ confluency were incubated with 4-20 PFU per cell in a final volume of 50 $\mu$ I DMEM supplemented with $10 \%$ calf serum for half an hour at room temperature with intermittent agitation. After infection, $3 \mathrm{ml}$ of growth medium was added into each of a 6-well plate and cells were grown for different times, as indicated in the results. Infected cells were analyzed microscopically.

For the cytokine assay, Hep-2 cells growing in a six-well plate were pretreated for $18 \mathrm{hr}$ with recombinant human INFB at $10^{4}$ $\mathrm{U} / \mathrm{ml}$ (Biosource International). The medium was removed and cells were infected with Ad5 mutant virus. After infection, conditioned medium was supplemented with fresh INF- $\beta$ for indicated times. For BrdU pulse-labeling, infected cells were incubated with $10 \mu \mathrm{M}$ BrdU for $10 \mathrm{~min}$, fixed, and analyzed microscopically.

For transient transfections, CV1 and Hep- 2 cells were grown on round glass coverslips in the corresponding medium, in sixwell plate to $50 \%-60 \%$ confluency. Twelve hours later the cells were transfected transiently with the indicated expression vectors using the $\mathrm{Ca}^{2+}$ precipitation technique as described previously (Wigler et al. 1977) or by lipofection with Dotap (Boehringer Mannheim). For a six-well plate, $1-3 \mu \mathrm{g}$ of the indicated expression vector driven by SV40 or CMV promoter was used in the transfection. The cells were fixed and tested by indirect immunofluorescence 16-20 hr after transfection. Cells were an- alyzed as for the expression levels of different proteins and the localization of the overexpressed or the endogenous proteins in the nuclei.

Hep-2 cells stably overexpressing PML were prepared by transient transfection of the pcDNA3-PML expression vector and selected with G418 (Geneticin) for neomycin-resistant clones. After selection 12 independent clones and a pool of positive clones were isolated and tested for PML overexpression by immunofluorescence (data not shown). The Hep-2 cells stably expressing PML were defined as Hep-2 LPIS cells. Four independent LPIS clones (LPIS1-LPIS4) and a pool of positives clones (LPIS-pool) were tested for adenovirus DNA replication and were compared to wild-type Hep-2 cells. Hep-2 cells stably expressing a pcDNA3 empty vector gave the same results as the Hep-2 wild-type cells in term of viral replication (Fig. 7a; data not shown).

\section{Cloning and expression vectors}

The E4-ORF3 gene product that codes for the $11-\mathrm{kD}$ Ad5 protein was cloned by PCR using as template a restriction fragment of Ad5 viral DNA, a HindIII DNA fragment positioned between 91.3 and 99.1 m.u., cloned in a Bluescript vector (provided by Dr. T. Shenk, Princeton University, NJ). The $5^{\prime}$ and $3^{\prime}$ primers used for the amplification of the ORF3 were 5'-GCGGAATTCATGATTCGCTGCTTGAGGCTGAAG-3' and 5'-GGCGGATCCTTATTCCAAAAGATTATCCAAAAC-3', respectively, producing an $E c O R I$ restriction site upstream of the initiation codon and a BamHI site at the $3^{\prime}$ end of the ORF3-coding sequence. The PCR fragment was cloned in the EcoRI-BamHI of the CMX-pL2 vector (Kakizuka et al. 1991). The CMXHA.ORF3 expression vector codes for the influenza hemagglutinin epitope (HA) (Niman et al. 1983) in-frame with the ORF3 sequence. This expression vector was constructed by cloning an oligonucleotide encoding the HA epitope $\left(5^{\prime}\right.$-AATTCATGGTCTATCCTTATGACGTCCCTGACTATGCCAGCCTGC-3') into the EcoRI site of the CMX-ORF3 expression vector. The authenticity of all PCR products were verified by sequencing. The CMV-ORF6 was kindly provided by Dr. G. Akusjarvi (Karolinska Institute, Stockholm, Sweden). The CMX-PML was described previously (Kakizuka et al. 1991) and the CMX-Sp100 was constructed by cloning the Sp-100 coding sequence downstream of the CMV promoter (Maul et al. 1995). The pSVPML

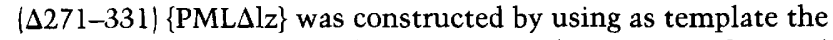
pSVPML-RAR ( $\Delta 271-331)$ construction (Doucas et al. 1993) and deleting the corresponding RAR sequence.

The pcDNA3-PML expression vector was constructed by cloning PML in the EcoRI restriction site of the pcDNA3 vector (Invitrogen) under CMV promoter. The pcDNA3 plasmid codes for the neomycin gene under the control of the SV40 promoter.

\section{Immunohistochemistry}

Two fixation methods were used for Hep-2 and CV1 cells. (1) The cells were fixed at room temperature for $5 \mathrm{~min}$ with freshly prepared $1 \%$ paraformaldehyde in PBS, washed with PBS, and permeabilized for $20 \mathrm{~min}$ on ice with $0.2 \%$ Triton X-100 in PBS (vol/vol) (Sigma Chemical Co.). Antigen localization was determined after incubation of permeabilized cells with rabbit antiserum or monoclonal antibody diluted in PBS for $1 \mathrm{hr}$ at room temperature. Avidin-fluorescein or avidin-Texas Red was complexed with primary antibodies through biotinylated secondary antibodies (Vector Labs Inc.). Cells were double labeled with the respective second antibodies labeled either with FITC or Texas Red, using FITC for the structures with the lowest staining 
intensity. (2) Alternatively, the cells were fixed at $-20^{\circ} \mathrm{C}$ for 5 min with fresh and cold acetone followed by fresh and cold absolute methanol. Fixed cells on coverslips were incubated with the first antibody diluted in PBS and $10 \%$ calf serum for 2 $\mathrm{hr}$ at room temperature in a humidified chamber. Coverslips were washed for $10 \mathrm{~min}$ in PBS and $0.05 \%$ Tween 20 . The conjugated to fluorescein or Texas Red second monoclonal antibodies (Jackson Lab.) were applied for $1 \mathrm{hr}$ at room temperature in the humidified chamber. For double immunofluorescence, permeabilized cells were incubated with the two antibodies under the same conditions. Cells were then stained for DNA with 0.5 $\mu \mathrm{g} / \mathrm{ml}$ of bis-benzimide (Hoecht 33258; Sigma) in PBS or with $0.5 \mu \mathrm{g} / \mathrm{ml}$ of DAPI and mounted with gelvatol or Fluoromount $\mathrm{G}$ (Fischer Scientific). The two fixation methods gave similar results.

Fluorescence images were analyzed using either the Leica confocal scanning microscope or a Nikon Microphot-SA immunofluorescence microscope. Confocal images represent single optical sections obtained either by simultaneous or sequential scanning.

Affinity-purified polyclonal rabbit antiserum against human PML-1 was raised against a peptide (amino acids 14-52) (antibody 1124) and used in dilution 1:100 (Kakizuka et al. 1991; Dyck et al. 1994). Similar results were obtained with a PML antibody raised against the 303 amino-terminal amino acids of the PML-1 protein, antibody 5114 (data not shown). Rabbit antibodies against $\mathrm{Sp}-100$ were received from Dr. C. Szostecki (Heinrich-Pette-Institut, Hamburg, Germany). The mAb 1150 recognizes Sp-100 (Maul et al. 1995). The two Sp-100 antibodies gave similar results (data not shown). The mAb 5E10 was generated against a nuclear matrix protein complex (Stuurman et al. 1992) and recognizes PML (Maul et al. 1995 ).

The E1B $55-\mathrm{kD}$ specific monoclonal antibody (clone 2A6) (Sarnow et al. 1982c) and monoclonal antibody E1B 55-kD (Oncogene Sc.), the E2A 72-kD specific monoclonal antibody (clone B6-8) (Reich et al. 1983), the E4-ORF6 M45-specific monoclonal antibody (Obert et al. 1994) were all used in 1:100 or 1:200 dilution. Influenza epitope-tagged protein was detected in immunohistochemistry with mAb 12CA5 (Boehringer Mannheim) raised against influenza HA peptide HAl (Niman et al. 1983).

\section{Southern analysis transfer}

Total DNA from infected cells was isolated, and $10 \mu \mathrm{g}$ was digested with HindIII endonuclease. DNA was analyzed on a $0.7 \%$ agarose $/ 1 \%$ TBE gel and then transferred to a nitrocellulose membrane. The ElA probe (a HindIII Ad5 DNA fragment) was labeled by random priming and hybridized to the nitrocellulose filter at $65^{\circ} \mathrm{C}$. The membrane was washed for $1 \mathrm{hr}$ at room temperature in $2 \times \mathrm{SSC} / 0.1 \%$ SDS and for $1 \mathrm{hr}$ at $65^{\circ} \mathrm{C}$ in $0.2 \times$ SSC $/ 0.1 \%$ SDS. The size of the E1A terminal HindIII fragment from a monomer genome is $2.8-\mathrm{kD}$ in Ad5 and d1366* + ORF3, as shown in the Results (Weiden and Ginsberg 1994). The corresponding radioactive signal to ElA probe that hybridized to the filter was counted (PhosphorImager), and the values obtained are presented in the results as arbitrary units.

\section{Acknowledgments}

We thank Dr. Patrick Hearing for providing us with crucial Ad5 viral mutants, Dr. Akusjarvi for ORF6 expression vector, Dr. Garry Ketner for d11004, and Dr. Harold Ginsberg for dl1 10 viral mutants. We are indebted to Dr. Thomas Shenk for providing us with Ad5 viral mutants, antibodies, and helpful discussions. We thank Drs. Miyamoto Shigeki and Inder Verma for their help in the initiation of these experiments. We thank Drs. Alex Almasan and John Shwabe for helpful comments and advice. We thank Elaine Stevens for the preparation of the manuscript and Multimedia Resources at the Salk Institute for their excellent work. V.D. is a Human Frontier Science Program (HFSP) postdoctoral fellow. A.M.I. is a postdoctoral fellow at the Wistar Institute and is supported by the Mathers Foundation. A.R. and H.J. are research assistants at the Salk Institute. M.D.W. is a postdoctoral fellow at the Human Gene Therapy Institute (University of Pennsylvania, Philadelphia). G.G.M. is supported by Wistar Institute funds. R.M.E is an Investigator of the Howard Hughes Medical Institute at the Salk Institute for Biological Studies. This study was also supported by National Institutes of Health Program Project CA54418 (R.M.E.).

The publication costs of this article were defrayed in part by payment of page charges. This article must therefore be hereby marked "advertisement" in accordance with 18 USC section 1734 solely to indicate this fact.

\section{References}

Akusjarvi, G. 1993. Proteins with transcription regulatory properties encoded by human adenoviruses. Trends Microbiol. 1: $163-170$.

Ascoli, C.A. and G.G. Maul. 1991. Identification of a novel nuclear domain. J. Cell Biol. 112: 785-795.

Babiss, L.E. and H.S. Ginsberg. 1984. Adenovirus type 5 early region $1 \mathrm{~b}$ gene product is required for efficient shutoff of host protein synthesis. J. Virol. 50: 202-212.

Bargonetti, J., I. Reynisdottir, P.N. Friedman, and C. Prives. 1992. Site-specific binding of wild-type p53 to cellular DNA is inhibited by SV40 T antigen and mutant p53. Genes \& Dev. 6: 1886-1898.

Berezney, R. and D.S. Coffey. 1976. The nuclear protein matrix: Isolation, structure, and functions. Adv. Enzyme Regul. 14: 63-100.

Berk, A.J. 1986. Adenovirus promoters and ElA transactivation. Annu. Rev. Genet. 20: 45-79.

Berk, A.J. and P.A. Sharp. 1978. Structure of the adenovirus 2 early mRNAs. Cell 14: 695-711.

Berkner, K.L. 1992. Expression of heterologous sequences in adenoviral vectors. Curr. Top. Microbiol. Immunol. 158: 3966.

Bosher, J., A. Dawson, and R.T. Hay. 1992. Nuclear factor I is specifically targeted to discrete subnuclear sites in adenovirus type 2-infected cells. J. Virol. 66: 3140-3150.

Bridge, E. and G. Ketner. 1989. Redundant control of adenovirus late gene expression by early region 4. J. Virol. 63: 631-638.

Brough, D.E., V. Cleghon, and D.F. Klessig. 1992. Construction, characterization, and utilization of cell lines which inducibly express the adenovirus DNA-binding protein. Virology 190: 624-634.

Castaigne, S., C. Chomienne, M.T. Daniel, P. Ballerini, R. Berger, P. Fenaux, and L. Degos. 1990. All-trans retinoic acid as a differentiation therapy for acute promyelocytic leukemia. I. Clinical results [see comments]. Blood 76: 17041709.

Chang, K.S., S.A. Stass, D.T. Chu, L.L. Deaven, J.M. Trujillo, and E.J. Freireich. 1992. Characterization of a fusion cDNA (RARA/myl) transcribed from the $t(15 ; 17)$ translocation breakpoint in acute promyelocytic leukemia. Mol. Cell Biol. 12: 800-810.

Cutt, J.R., T. Shenk, and P. Hearing. 1987. Analysis of adenovirus early region 4-encoded polypeptides synthesized in productively infected cells. I. Virol. 61: 543-552. 
de Thé, H., C. Lavau, A. Marchio, C. Chomienne, L. Degos, and A. Dejean. 1991. The PML-RAR alpha fusion mRNA generated by the $t(15 ; 17)$ translocation in acute promyelocytic leukemia encodes a functionally altered RAR. Cell 66: 675684.

Doucas, V., J.P. Brockes, M. Yaniv, H. de Thé, and A. Dejean. 1993. The PML-retinoic acid receptor alpha translocation converts the receptor from an inhibitor to a retinoic aciddependent activator of transcription factor AP-1. Proc. Natl. Acad. Sci. 90: 9345-9349.

Dyck, J.A., G.G. Maul, W. Miller Jr., J.D. Chen, A. Kakizuka, and R.M. Evans. 1994. A novel macromolecular structure is a target of the promyelocyte-retinoic acid receptor oncoprotein. Cell 76: 333-343.

Dyson, N., K. Buchkovich, P. Whyte, and E. Harlow. 1989. The cellular $107 \mathrm{~K}$ protein that binds to adenovirus E1A also associates with the large T antigens of SV40 and JC virus. Cell 58: $249-255$.

Freemont, P.S., I.M. Hanson and J. Trowsdale. 1991. A novel cysteine-rich sequence motif [Letter]. Cell 64: 483-484.

Freyer, G.A., Y. Katoh, and R.J. Roberts. 1984. Characterization of the major mRNAs from adenovirus 2 early region 4 by cDNA cloning and sequencing. Nucleic Acids Res. 12: 3503-3519.

Goddard, A.D., J. Borrow, and E. Solomon. 1992. A previously uncharacterized gene, $\mathrm{PML}$, is fused to the retinoic acid receptor alpha gene in acute promyelocytic leukaemia. Leukemia 6: 117S-119S.

Graham, F.L., J. Smiley, W.C. Russell, and R. Nairn. 1977. Characteristics of a human cell line transformed by DNA from human adenovirus type 5. I. Gen. Virol. 36: 59-74.

Grignani, F., P.F. Ferrucci, U. Testa, G. Talamo, M. Fagioli, M. Alcalay, A. Mencarelli, F. Grignani, C. Peschle, I. Nicoletti, et al. 1993. The acute promyelocytic leukemia-specific PML-RAR alpha fusion protein inhibits differentiation and promotes survival of myeloid precursor cells. Cell 74: 423431.

Guldner, H.H., C. Szostecki, T. Grotzinger, and H. Will. 1992. IFN enhance expression of Sp100, an autoantigen in primary biliary cirrhosis. J. Immunol. 149: 4067-4073.

Halbert, D.N., J.R. Cutt, and T. Shenk. 1985. Adenovirus early region 4 encodes functions required for efficient DNA replication, late gene expression, and host cell shutoff. I. Virol. 56: 250-257.

Herisse, J., M. Rigolet, S.D. de Dinechin, and F. Galibert. 1981. Nucleotide sequence of adenovirus 2 DNA fragment encoding for the carboxylic region of the fiber protein and the entire E4 region. Nucleic Acids Res. 9: 4023-4042.

Huang, M.E., Y.C. Ye, S.R. Chen, J.R. Chai, J.X. Lu, L. Zhoa, L.J. $\mathrm{Gu}$, and Z.Y. Wang. 1988. Use of all-trans retinoic acid in the treatment of acute promyelocytic leukemia. Blood 72: 567572.

Huang, M.M. and P. Hearing. 1989. Adenovirus early region 4 encodes two gene products with redundant effects in lytic infection. J. Virol. 63: 2605-2615.

Jimenez-Garcia, L.F. and D.L. Spector. 1993. In vivo evidence that transcription and splicing are coordinated by a recruiting mechanism. Cell 73: 47-59.

Jones, N. and T. Shenk. 1979. Isolation of adenovirus type 5 host range deletion mutants defective for transformation of rat embryo cells. Cell 17: 683-689.

Kakizuka, A., W. Miller Jr., K. Umesono, R. Warrell Jr., S.R. Frankel, V.V. Murty, E. Dmitrovsky, and R.M. Evans. 1991. Chromosomal translocation $t\{15 ; 17\}$ in human acute promyelocytic leukemia fuses RAR alpha with a novel putative transcription factor, PML. Cell 66: 663-674.

Kastner, P., A. Perez, Y. Lutz, C. Rochette-Egly, M.P. Gaub, B. Durand, M. Lanotte, R. Berger, and P. Chambon. 1992. Structure, localization and transcriptional properties of two classes of retinoic acid receptor alpha fusion proteins in acute promyelocytic leukemia (APL): Structural similarities with a new family of oncoproteins. EMBO I. 11: 629-642.

Kenny, M.K., L.A. Balogh, and J. Hurwitz. 1988. Initiation of adenovirus DNA replication. I. Mechanism of action of a host protein required for replication of adenovirus DNA templates devoid of the terminal protein. I. Biol. Chem. 263: 9801-9808.

Khittoo, G., L. Delorme, C.V. Dery, M.L. Tremblay, J.M. Weber, V. Bibor-Hardy, and R. Simard. 1986. Role of the nuclear matrix in adenovinus maturation. Virus Res. 4: 391-403.

Koken, M.H., F. Puvion-Dutilleul, M.C. Guillemin, A. Viron, G. Linares-Cruz, N. Stuurman, L. de Jong, C. Szostecki, F. Calvo, C. Chomienne, et al. 1994 . The $t(15 ; 17)$ translocation alters a nuclear body in a retinoic acid-reversible fashion. EMBO J. 13: 1073-1083.

Kozarsky, K., M. Grossman, and J.M. Wilson. 1993. Adenovirusmediated correction of the genetic defect in hepatocytes from patients with familial hypercholesterolemia. Somat. Cell Mol. Genet. 19: 449-458.

Levine, A.J. 1984. The adenovirus early proteins. Curr. Top. Microbiol. Immunol. 110: 143-167.

Mariman, E.C., C.A. van Eekelen, R.J. Reinders, A.J. Berns, and W.J. van Venrooij. 1982. Adenoviral heterogeneous nuclear RNA is associated with the host nuclear matrix during splicing. I. Mol. Biol. 154: 103-119.

Maul, G.G., E. Yu, A.M. Ishov, and A.L. Epstein. 1995. Nuclear domain 10 (ND10) associated proteins are present in nuclear bodies and redistributed to hundreds of nuclear sites after stress. J. Cell Biochem. 59: 499-514.

Mitelman, F. 1988. Catalog of chromosome aberrations in cancer, 3rd ed. Allen Liss, New York.

Mul, Y.M., C.P. Verrijzer, and P.C. van der Vliet. 1990. Transcription factors NFI and NFIII/oct-1 function independently, employing different mechanisms to enhance adenovirus DNA replication. /. Virol. 64: 5510-5518.

Nevins, J.R. 1987. Regulation of early adenovirus gene expression. Microbiol. Rev. 51: 419-430.

Niman, H.L., R.A. Houghten, L.E. Walker, R.A. Reisfeld, I.A. Wilson, J.M. Hogle, and R.A. Lerner. 1983. Generation of protein-reactive antibodies by short peptides is an event of high frequency: Implications for the structural basis of immune recognition. Proc. Natl. Acad. Sci. 80: 4949-4953.

Obert, S., R.J. O'Connor, S. Schmid, and P. Hearing. 1994. The adenovirus E4-6/7 protein transactivates the E2 promoter by inducing dimerization of a heteromeric E2F complex. Mol. Cell Biol. 14: 1333-1346.

Ornelles, D.A. and T. Shenk. 1991. Localization of the adenovirus early region $\mathrm{B}$ 55-kilodalton protein during lytic infection: Association with nuclear viral inclusions requires the early region 4 34-kilodalton protein. I. Virol. 65: 424429.

Pandolfi, P.P., F. Grignani, M. Alcalay, A. Mencarelli, A. Biondi, F. LoCoco, F. Grignani, and P.G. Pelicci. 1991. Structure and origin of the acute promyelocytic leukemia myl/RAR alpha cDNA and characterization of its retinoid-binding and transactivation properties. Oncogene 6: 1285-1292.

Perez, A., P. Kastner, S. Sethi, Y. Lutz, C. Reibel, and P. Chambon. 1993. PMLRAR homodimers: Distinct DNA binding properties and heteromeric interactions with RXR. EMBO $\%$ 12: $3171-3182$. 
Pilder, S., M. Moore, J. Logan, and T. Shenk. 1986. The adenovirus E1B-55K transforming polypeptide modulates transport or cytoplasmic stabilization of viral and host cell $\mathrm{mR}$ NAs. Mol. Cell Biol. 6: 470-476.

Pombo, A., J. Ferreira, E. Bridge, and M. Carmo-Fonseca. 1994. Adenovirus replication and transcription sites are spatially separated in the nucleus of infected cells. EMBO J. 13: 50755085.

Puvion-Dutilleul, F., R. Roussev, and E. Puvion. 1992. Distribution of viral RNA molecules during the adenovirus type 5 infectious cycle in HeLa cells. I. Struct. Biol. 108: 209-220.

Reich, N.C., P. Sarnow, E. Duprey, and A.J. Levine. 1983. Monoclonal antibodies which recognize native and denatured forms of the adenovirus DNA-binding protein. Virology 128: $480-484$.

Rice, S.A. and D.F. Klessig. 1985. Isolation and analysis of adenovirus type 5 mutants containing deletions in the gene encoding the DNA-binding protein. I. Virol. 56: 767-778.

Sarnow, P., Y.S. Ho, J. Williams, and A.J. Levine 1982a. Adenovirus Elb-58kd tumor antigen and SV40 large tumor antigen are physically associated with the same $54 \mathrm{kd}$ cellular protein in transformed cells. Cell 28: 387-394.

Sarnow, P., P. Hearing, C.W. Anderson, N. Reich, and A.J. Levine. 1982b. Identification and characterization of an immunologically conserved adenovirus early region $11,000 \mathrm{Mr}$ protein and its association with the nuclear matrix. J. Mol. Biol. 162: 565-583.

Sarnow, P., C.A. Sullivan, and A.J. Levine. 1982c. A monoclonal antibody detecting the adenovirus type $5-\mathrm{E} 1 \mathrm{~b}-58 \mathrm{Kd}$ tumor antigen: Characterization of the $\mathrm{E} / \mathrm{b}-58 \mathrm{Kd}$ tumor antigen in adenovirus-infected and -transformed cells. Virology 120: 510-517.

Sarnow, P., P. Hearing, C.W. Anderson, D.N. Halbert, T. Shenk, and A.J. Levine. 1984. Adenovirus early region 1B 58,000dalton tumor antigen is physically associated with an early region 425,000 -dalton protein in productively infected cells. I. Virol. 49: 692-700.

Schaack, J., W.Y. Ho, P. Freimuth, and T. Shenk. 1990. Adenovirus terminal protein mediates both nuclear matrix association and efficient transcription of adenovirus DNA. Genes \& Dev. 4: 1197-1208.

Schneider, R.J. and T. Shenk. 1987. Impact of virus infection on host cell protein synthesis. Annu. Rev. Biochem. 56: 317332.

Shirodkar, S., M. Ewen, J.A. DeCaprio, J. Morgan, D.M. Livingston, and T. Chittenden. 1992. The transcription factor E2F interacts with the retinoblastoma product and a p107-cyclin A complex in a cell cycle-regulated manner. Cell 68: 157166.

Stuurman, N., A. de Graaf, A. Floore, A. Josso, B. Humbel, L. de Jong, and R. van Driel. 1992. A monoclonal antibody recognizing nuclear matrix-associated nuclear bodies. J. Cell Sci. 101: 773-784.

Tigges, M.A. and H.J. Raskas. 1984. Splice junctions in adenovirus 2 early region 4 mRNAs: Multiple splice sites produce 18 to 24 RNAs. J. Virol. 50: 106-117.

Virtanen, A., P. Gilardi, A. Naslund, I.M. LeMoullec, U. Pettersson, and M. Perricaudet. 1984. mRNAs from human adenovirus 2 early region 4 . J. Virol. 51: 822-831.

Weiden, M.D. and H.S. Ginsberg. 1994. Deletion of the E4 region of the genome produces adenovirus DNA concatemers. Proc. Natl. Acad. Sci. 91: 153-157.

Weinberg, D.H. and G. Ketner. 1983. A cell line that supports the growth of a defective early region 4 deletion mutant of human adenovirus type 2. Proc. Natl. Acad. Sci. 80: 5383-
5386.

- 1986. Adenoviral early region 4 is required for efficient viral DNA replication and for late gene expression. $/$. Virol. 57: 833-838.

Weis, K., S. Rambaud, C. Lavau, J. Jansen, T. Carvalho, M. Carmo-Fonseca, A. Lamond, and A. Dejean. 1994. Retinoic acid regulates aberrant nuclear localization of PML-RAR alpha in acute promyelocytic leukemia cells. Cell 76: 345356.

Wigler, M., S. Silverstein, L.S. Lee, A. Pellicer, Y. Cheng, and R. Axel. 1977. Transfer of purified herpes virus thymidine kinase gene to cultured mouse cells. Cell 11: 223-232.

Yew, P.R., X. Liu, and A.J. Berk. 1994. Adenovirus E1B oncoprotein tethers a transcriptional repression domain to $\mathrm{p} 53$. Genes \& Dev. 8: 190-202.

Younghusband, H.B. and K. Maundrell. 1982. Adenovirus DNA is associated with the nuclear matrix of infected cells. $J$. Virol. 43: 705-713.

Zhai, Z.H., J.A. Nickerson, G. Krochmalnic, and S. Penman. 1987. Alterations in nuclear matrix structure after adenovirus infection. J. Virol. 61: 1007-1018. 


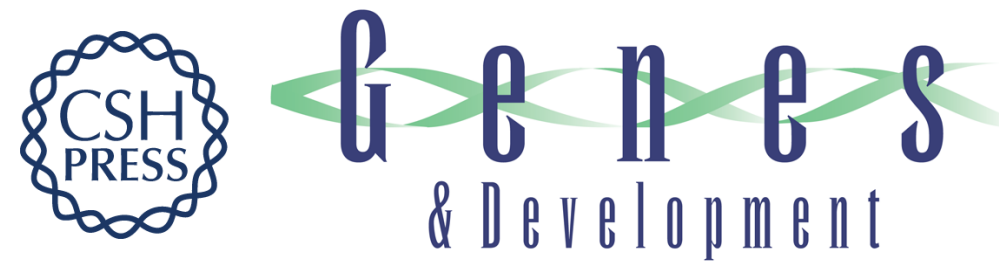

\title{
Adenovirus replication is coupled with the dynamic properties of the PML nuclear structure.
}

\author{
V Doucas, A M Ishov, A Romo, et al.
}

Genes Dev. 1996, 10:

Access the most recent version at doi:10.1101/gad.10.2.196

References This article cites 69 articles, 32 of which can be accessed free at:

http://genesdev.cshlp.org/content/10/2/196.full.html\#ref-list-1

License

Email Alerting

Service

Receive free email alerts when new articles cite this article - sign up in the box at the top right corner of the article or click here.

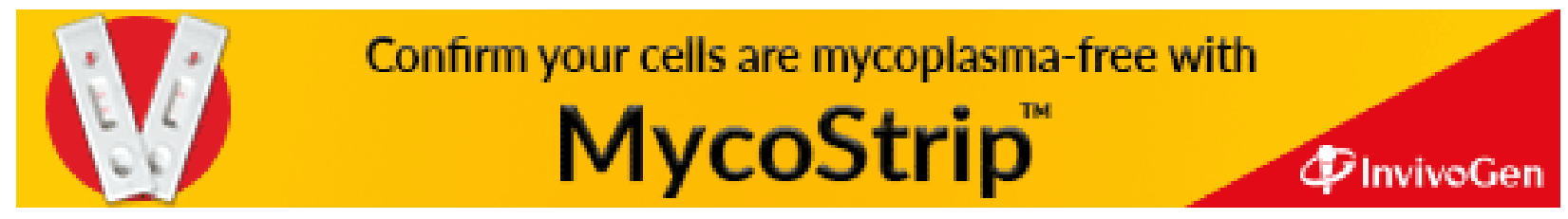

